\title{
Tingkat Stres Ibu Menyusui dan Pemberian Asi pada Bulan Pertama
}

\section{Stress Levels of Breastfeeding Mothers and Breast Milk In The First Month}

\author{
Zuly Daima Ulfa') a)*, Yuli Setyaningsih ${ }^{2)}$ b) \\ 1)Universitas Palangka Raya, Program Studi Jasmani, Kesehatan dan Rekreasi \\ a)Jl. Kartini, Palangka Raya. 74874. Kalimantan Tengah \\ 2)Puskesmas Tayu I, Pati \\ b)Jl. P. Sudirman No. 17 Tayu, Pati. 59155. Jawa Tengah \\ *Email: zuly.syaifun@gmail.com
}

\begin{abstract}
Stress on maternal can inhibit breastmilk production so that it disrupts lactation. Stress occurs in the first month after birth delivery as the adaptation of new roles. This condition causes mothers give up on breastfeeding early and it affects the sustainibility of exclusive breastfeeding as ideal nutrition for infant. The aim of the study was to analyze the relationship between stress levels of breastfeeding mothers and behavior of giving the breast milk in the first month. This study used a cross sectional approach which was carried out in the working area of Community Health Center of Tayu I. The sampling technique was purposive sampling. The results showed that breastfeeding mothers who suffered from stress in the first month were as many as $42.5 \%$, consisting of $25 \%$ mild stress, $15 \%$ moderate stress and $2.5 \%$ severe stress. Breastfeeding in the first month was as many as $75 \%$, carried out by mothers not sufferring stress and those suffering mild and moderate stress. The results of chi square analysis obtained $\rho 0.041$ which means that there was a correlation between stress levels of breastfeeding mothers in the first month. The Odds Ratio (OR) was as many as 9,33 $(95 \% \mathrm{Cl}=1,38,63,20)$ which means that mothers who suffered from moderate-high level of stress had as many as 9,33 times of possibility not to breastfeeding in the first month. Breastfeeding mothers who did not suffer from stress and suffer mild level of stress were more likely to keep breastfeeding in the first month.
\end{abstract}

Keywords: exclusive breastfeeding, breastfeeding, stress

\begin{abstract}
ABSTRAK
Stres pada ibu dapat menghambat pengeluaran ASI. Stres sering dialami pada bulan pertama setelah persalinan sebagai adaptasi menjalankan peran baru. Keadaan tersebut dapat membuat ibu berhenti menyusui lebih awal yang berpengaruh pada keberlangsungan pemberian ASI Eksklusif sementara ASI adalah nutrisi terbaik bagi bayi. Tujuan penelitian untuk menganalisis hubungan tingkat stres ibu menyusui dengan pemberian ASI pada bulan pertama. Penelitian ini menggunakan pendekatan cross sectional, dilakukan di wilayah kerja Puskesmas Tayu I. Teknik pengambilan sampel dilakukan secara sampling purposive. Hasil penelitian menunjukkan ibu menyusui pada bulan pertama yang mengalami stres sebanyak 42,5\%; terdiri stres ringan 25\%; stres sedang 15\%; dan stres berat 2,5\%. Pemberian ASI pada bulan pertama sebesar 75\%, dilakukan oleh ibu yang tidak mengalami stres maupun ibu yang mengalami stres ringan dan sedang. Berdasarkan analisis chi square didapatkan $\rho 0,041 ;$ yang berarti ada hubungan tingkat stres ibu menyusui dengan pemberian ASI pada bulan pertama. Odds Ratio (OR) sebesar 9,33 (95\% CI=1,38, 63,20) yang berarti ibu dengan tingkat stres sedang-berat mempunyai kemungkinan 9,33 lebih besar untuk tidak memberikan ASI pada bulan pertama. Ibu menyusui yang tidak mengalami stres atau mengalami stres dalam fase ringan mempunyai kemungkinan lebih besar untuk tetap melakukan pemberian ASI pada bulan pertama.
\end{abstract}

Kata kunci : ASI eksklusif, menyusui, stres

\section{PENDAHULUAN}

WHO merekomendasikan ASI (Air Susu Ibu) eksklusif untuk 6 bulan pertama kehidupan. Pemberian ASI secara optimal sangat penting karena dapat menyelamatkan lebih dari
800.000 nyawa anak balita setiap tahunnya, namun fakta menunjukkan hanya $43 \%$ saja bayi umur 0-6 bulan yang diberikan ASI secara eksklusif (WHO, 2016). ASI merupakan nutrisi ideal untuk bayi karena mengandung zat gizi yang paling sesuai dengan kebutuhan bayi dan 
bayi serta mengandung seperangkat zat perlindungan terhadap berbagai penyakit. Dampak apabila bayi tidak diberikan ASI pada bulan pertama diyakini dapat meningkatkan 1/3 kejadian Infeksi Saluran Pernapasan Atas (ISPA), kejadian diare dapat meningkat $50 \%$, dan penyakit usus parah pada bayi prematur dapat meningkat kejadiannya sebanyak 58\% (Kementerian Kesehatan RI, 2014).

Neonatus atau bayi baru lahir yang diberi ASI secara eksklusif memiliki risiko kematian akibat infeksi pada bulan pertama lebih rendah dibandingkan neonatus yang disusui sebagian (tidak eksklusif selama 6 bulan). Promosi yang efektif mengenai inisiasi menyusui dini serta menyusui eksklusif selama bulan pertama kehidupan memiliki manfaat besar dalam mengurangi mortalitas dan morbiditas neonatal (Khan et al., 2015).

Persentase bayi yang mendapatkan ASI eksklusif di Indonesia pada tahun 2017 sebesar $35,73 \%$, masih jauh di bawah target nasional yaitu $80 \%$. Cakupan ASI eksklusif di Provinsi Jawa Tengah mencapai 41,89\%, sedangkan target pencapaian pemberian ASI di Jawa Tengah sebesar 55\%. Angka tersebut lebih rendah dibandingkan tahun 2016 yakni sebesar 45,18\% (Kementerian Kesehatan, 2018).

Cakupan pemberian ASI di Kabupaten Pati tahun 2017 sebesar 76,8\%. Angka tersebut naik jika dibandingkan tahun 2016 yaitu 74,2\%, meskipun masih di bawah target nasional. Cakupan tertinggi terdapat di Puskesmas Tayu II (96,7 \%), sementara Puskesmas Tayu I yang lokasinya masih 1 kecamatan, menduduki rangking 4 (empat) terbawah untuk cakupan terendah ASI di Kabupaten Pati yakni sebesar 62,3\% (Dinas Kesehatan Kabupaten Pati, 2018).

Hasil studi pendahuluan di wilayah kerja Puskesmas Tayu I Kabupaten Pati, sebanyak 75 $\%$ ibu mengalami stres karena ASI tidak keluar dengan lancar dan sebanyak 60\% ibu mengatakan kasihan terhadap anaknya karena masih rewel dan menangis kalau hanya diberikan ASI saja. Sebagian kecil (20\%) memperoleh informasi dari orang-orang yang lebih tua di desa tersebut untuk memberikan makanan (pisang, bubur) dan menganggap bahwa memberikan makanan pada bayi dengan umur kurang dari 6 bulan tidak berdampak negatif pada bayi.

Pemberian ASI dipengaruhi kesehatan fisik dan mental, jenis persalinan yang direncanakan, pendapatan, pendidikan, paritas, etnis, dan kesulitan menyusui. Wanita dengan jenis persalinan caesar yang direncanakan memiliki kemungkinan lebih besar $(\mathrm{OR}=1,61$; 95\% CI: 1,14, 2,26; $p=0,014$ ) untuk menghentikan menyusui sebelum 12 minggu pascapersalinan dibandingkan dengan mereka yang melahirkan secara vagina (Hobbs et al., 2016).

Kendala pemberian ASI terutama pada periode awal setelah melahirkan yaitu ASI yang tidak lancar karena ibu kelelahan akibat proses persalinan, takut mobilisasi, terlebih ibu pasca persalinan SC (Section Caesaria) yang masih terpasang infus dan kateter sehingga malas menyusui. Ibu cenderung memikirkan diri sendiri dan merasa berat merawat bayi. Kondisi tersebut memicu ketidaknyamanan sehingga menimbulkan stres (Amalia, 2016).

Stres adalah salah satu faktor yang dapat memengaruhi pemberian ASI, misalnya ibu mengalami kesulitan pada awal menyusui seperti kelelahan, ASI sedikit, puting susu lecet, dan gangguan tidur malam hari. Stres dapat berpengaruh terhadap produksi ASI karena menghambat pengeluaran ASI dan pada akhirnya akan berakibat pada pemberian ASI (Susanti, 2014).

Stres berpengaruh terhadap keberlangsungan pemberian ASI Eksklusif. Keberhasilan pemberian ASI berhubungan dengan produksi ASI sementara stres dapat memengaruhi produksi ASI. Ibu yang mengalami stres sedang yang berhasil memberikan ASI karena mendapat motivasi untuk meningkatkan produksi ASI. Motivasi berasal dari diri sendiri, lingkungan, keluarga, dan tenaga kesehatan (Elsanti \& Isnaini, 2018).

Kesulitan penyesuaian peran setelah persalinan, jika tidak segera dilakukan penanganan tepat dapat berdampak pada kesehatan dan kesejahteraan ibu dan bayinya. Beberapa hari setelah persalinan sampai bulan pertama seringkali mengalami masalah menyusui akibat 
adaptasi fisiologis setelah persalinan. Kondisi tersebut sering dialami ibu terutama pada pengalaman menyusui anak pertama sehingga peneliti mengkaji lebih mendalam tentang stres pada ibu menyusui dan pemberian ASI pada bulan pertama. Berdasarkan latar belakang tersebut, penelitian ini bertujuan menganalisis hubungan tingkat stres ibu menyusui dengan pemberian ASI pada bulan pertama di wilayah kerja Puskesmas Tayu I Kabupaten Pati.

\section{TINJAUAN PUSTAKA}

\section{Stres Ibu Menyusui}

Stres adalah stimulus atau situasi yang menimbulkan distress dan menciptakan tuntutan fisik dan psikis pada seseorang. Stres membutuhkan koping dan adaptasi. Respon tubuh dapat diprediksi tanpa memperhatikan stresor atau penyebab tertentu (Isaacs, 2012).

Kondisi yang membutuhkan koping dan adaptasi diantaranya adalah periode setelah persalinan. Kecemasan dapat bertambah pada periode tersebut. Ibu mengalami pengalaman yang unik karena terjadi perubahan peran dan tanggung jawab termasuk tugas menyusui. Tahap menjalankan peran tersebut dapat menjadi stressor ketika ibu mengalami kesulitan dan tidak dapat mengatasinya.

Stres dibedakan menjadi 3 (tiga) kategori, yaitu ringan, sedang, dan berat. Stres ringan adalah stresor yang dihadapi setiap orang secara teratur, berlangsung beberapa menit atau jam. Stres sedang berlangsung lebih lama, dari beberapa jam sampai beberapa hari. Stres berat adalah situasi kronis yang dapat berlangsung beberapa minggu sampai beberapa tahun (Potter \& Perry, 2012).

Stres ditinjau dari penyebabnya digolongkan menjadi stress fisik, kimiawi, mikrobiologik, fisiologik, psikis, dan proses pertumbuhan dan perkembangan. Stres fisik disebabkan oleh suhu yang terlalu tinggi atau rendah, suara bising, dan sinar yang terlalu terang. Stres kimiawi disebabkan obat-obatan, zat beracun, hormon, atau gas. Stres mikrobiologik disebabkan oleh virus, bakteri, atau parasit yang menimbulkan penyakit (Potter \& Perry, 2012).

Stres fisiologik disebabkan oleh proses fisiologi tubuh yang menjadi tidak normal yaitu gangguan struktur, fungsi jaringan, organ, atau sistemik. Stres proses pertumbuhan dan perkembangan terjadi akibat adanya gangguan pertumbuhan dan perkembangan pada masa bayi hingga tua. Stres psikis atau emosional disebabkan oleh gangguan hubungan interpersonal, sosial, budaya atau keagamaan (Potter \& Perry, 2012).

Stres berpotensi memberikan dampak negatif apabila jumlah sumber stres banyak, namun kemampuan yang dimiliki sedikit. Sebaliknya, jika sumber stres dalam kapasitas cukup dan sebanding dengan kemampuan, maka stres dapat berdampak positif. Stres pada individu berdasarkan teori mendasar yaitu stres model stimulus, respon, dan transaksional (Gaol, 2016).

Kondisi psikologis ibu memiliki hubungan dengan kelancaran produksi ASI, dimana semakin baik kondisi psikologis ibu, maka semakin baik pula produksi ASInya. Kondisi psikologis yang baik mendorong ibu untuk menyusui bayi sehingga hormon yang berperan dalam produksi ASI meningkat karena hisapan bayi ketika menyusui merangsang produksi ASI (Kamariyah, 2014).

Stres yang dialami pada masa kehamilan terkait dengan lama menyusui. Penelitian di Swedia menunjukkan variabel yang terkait pemberian ASI eksklusif yang berlangsung kurang dari dua bulan pasca persalinan yaitu pengalaman pertama menjadi ibu (AOR 2,15; 95\% CI 1,32-3,49), stres emosional selama kehamilan (AOR 2,21, 95\% CI 1,35-3,62) dan melahirkan melalui operasi caesar (AOR 2,63; 95\% CI 1,34-5,17) (Cato et al., 2017).

Stres dapat terjadi pada ibu yang memiliki harapan tinggi tentang perawatan bayi yang optimal namun tidak ditunjang dengan pengetahuan dan dukungan yang cukup. Stres pada masa awal setelah persalinan menyebabkan ibu menghentikan menyusui lebih awal, namun breastfeeding self efficacy yang tinggi membuat 
ibu lebih gigih untuk terus menyusui. Dukungan pada ibu menyusui berupa edukasi ASI eksklusif, demonstrasi cara menyusui, video teknik menyusui dan manajemen stres dapat meningkatkan breastfeeding self efficacy yang berhubungan dengan pemberian ASI (Pradanie, 2015).

\section{Pemberian ASI}

ASI Eksklusif adalah memberikan ASI saja kepada bayi tanpa tambahan makanan atau minuman lainnya termasuk air putih sampai bayi umur 6 bulan. Menyusui secara eksklusif memberikan manfaat bagi ibu dan bayi antara lain melindungi saluran pencernaan bayi dan encegah diare dan infeksi. Menyusui memberikan perlindungan bagi ibu terhadap risiko kanker payudara dan rahim serta memberi manfaat kontrasepsi selama 6 bulan menyusui (WHO, 2016).

Ujung saraf peraba pada puting susu menerima rangsang ketika ibu menyusui. Rangsangan tersebut dibawa ke hipotalamus di dasar otak, lalu memacu hipofase anterior untuk mengeluarkan hormon prolaktin ke dalam darah memacu sel kelenjar (alveoli) untuk memproduksi ASI. Aktifitas sekresi kelenjar susu senantiasa berubah-ubah, diantaranya dipengaruhi oleh psikis kejiwaan yang dialami oleh ibu (Roesli, 2012).

Produksi ASI sangat dipengaruhi oleh faktor kejiwaan. Ibu yang mengalami gangguan emosi, dapat mengganggu proses let down refleks yang berakibat ASI tidak keluar, sehingga bayi tidak mendapatkan ASI dalam jumlah yang cukup dan bayi pun akan terusmenerus menangis. Tangisan bayi juga membuat ibu menjadi gelisah dan menganggu proses let down refleks. Semakin tertekan perasaan ibu karena tangisan bayi, semakin sedikit ASI yang dikeluarkan (Roesli, 2012).

Menyusui merupakan proses biofisiopsikologis antara ibu dan anak demi kepentingan bersama. Kesadaran ibu untuk memberikan ASI eksklusif serta dukungan suami, keluarga, dan tenaga kesehatan menumbuhkan afeksi dan sikap positif yang mendukung keberhasilan menyusui (Wattimena, Susanti, \& Marsuyanto, 2012).

Pemberian ASI bermanfaat memberikan perlindungan terhadap penyakit dan kematian, serta menjauhkan dari risiko penyakit tidak menular (asma, kegemukan, diabetes, penyakit jantung) karena ASI merupakan nutrisi terbaik mulai jam pertama kehidupan sampai bayi umur 2 tahun. Pemberian ASI juga bermanfaat dalam perkembangan bayi dan meningkatkan kecerdasan. ASI disebut sebagai hak bagi setiap anak (UNICEF \& WHO, 2015).

Manfaat pemberian ASI pada kesehatan ibu yaitu mencegah perdarahan, mengurangi risiko kanker payudara dan rahim, penyakit kardiovaskuler, serta memberikan jarak dengan kehamilan berikutnya. Populasi yang terkendali juga berperan dalam meningkatkan akses terhadap pelayanan kesehatan. Pemberian ASI ber - arti memberikan makanan terbarukan yang tidak memerlukan kemasan, penyimpanan, pengiriman, pengolahan secara alamiah sehingga lebih ramah lingkungan (UNICEF \& WHO, 2015).

Pemberian ASI selama 6 bulan memerlukan manajemen diri yang kuat dalam sadar diri dan determinasi diri. Sadar diri memicu determinasi diri dengan menunjukkan aktualisasi potensi dalam suasana hati yang puas dan bahagia. Suasana positif ini berperan terhadap peningkatan kegiatan otak yang berperan pada regulasi fisiologi tubuh antara lain dalam produksi ASI (Wattimena dkk., 2015).

\section{METODE PENELITIAN}

Penelitian merupakan survei analitik dengan pendekatan crosssectional. Populasi adalah ibu yang memiliki bayi umur 0 - 6 bulan di wilayah kerja Puskesmas Tayu I Kabupaten Pati. Sampel dipilih berdasarkan kriteria umur bayi 0-1 bulan, anak pertama dan tidak terdiagnosa penyakit medis lain. Jumlah sampel adalah 40 orang. Teknik sampling menggunakan sampling purposive .

Pengambilan data dilakukan pada bulan Desember 2018. Instrumen menggunakan kuesioner. Pengukuran variabel tingkat stres 
ibu menyusui menggunakan model Perceived Stress Scale (PSS-10) yang dimodifikasi, sedangkan variabel pemberian ASI pada bulan pertama menggunakan kuesioner. Kategori stres diperoleh dari penjumlahan skor dalam PSS-10 adalah 0-40 kemudian dilakukan interpretasi berdasarkan skor tersebut.

Analisis univariat dilakukan untuk mendeskripsikan variabel menggunakan tabel distribusi frekuensi. Analisis bivariate untuk menganalisis hubungan antar variabel. Uji korelasional menggunakan chi square dengan nilai confidence interval sebesar $95 \%$.

Uji chi square menurut Arikunto (2013) harus memenuhi syarat apabila tabel lebih dari $2 \times 2$, maka tidak boleh ada sel yang mempunyai nilai harapan atau nilai harapan (E) $<5$ lebih dari $20 \%$ dari jumlah keseluruhan sel. Apabila tabel lebih dari $2 \times 2$, namun ada sel yang mempunyai nilai $\mathrm{E}<5$ lebih dari $20 \%$ dari jumlah keseluruhan sel, maka dilakukan penggabungan sel. Apabila tabel $2 \times 2$ dan tidak ada nilai $\mathrm{E}<5$, maka uji yang dipakai continuity correction atau yate's correction. Apabila tabel $2 \mathrm{x}$ 2 dan ada nilai $\mathrm{E}<5$, maka nilai uji yang digunakan adalah fisher's exact test.

\section{HASIL DAN PEMBAHASAN}

Penentuan responden penelitian dilihat berdasarkan kriteria umur bayi, paritas, dan pekerjaan. Responden adalah ibu menyusui yang berada di wilayah Puskesmas Tayu I dengan bayi umur 0-1 bulan. Semua responden adalah ibu yang mempunyai anak pertama sehingga memiliki kondisi yang serupa terkait perubahan pola hidup karena menyusui anak pertama. Semua responden tidak dalam kondisi bekerja, baik dalam masa cuti bersalin dari pekerjaan atau memang tidak bekerja.

Karakteristik responden dibedakan berdasarkan umur dan tingkat pendidikan. Umur responden beragam antara umur 18 - 36 tahun. Sebagian besar dalam usia reproduksi sehat yaitu kelompok umur 20-35 tahun. Responden yang tergolong dalam risiko tinggi (umur kurang dari 20 tahun atau lebih dari 35 tahun) sebanyak $20 \%$.

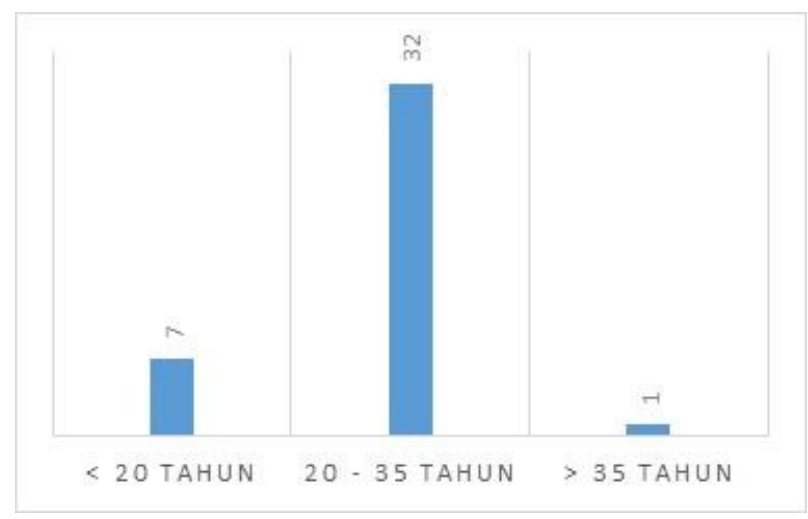

Gambar 1

Distribusi Responden Berdasarkan Umur

Tingkat pendidikan responden sebagian besar adalah SMP sebesar 48\% dan SMA sebesar $45 \%$. Penelitian dilakukan di wilayah yang memiliki fasilitas pendidikan maksimal jenjang SMA. Distribusi responden berdasarkan tingkat pendidikan disajikan pada Gambar 2 .

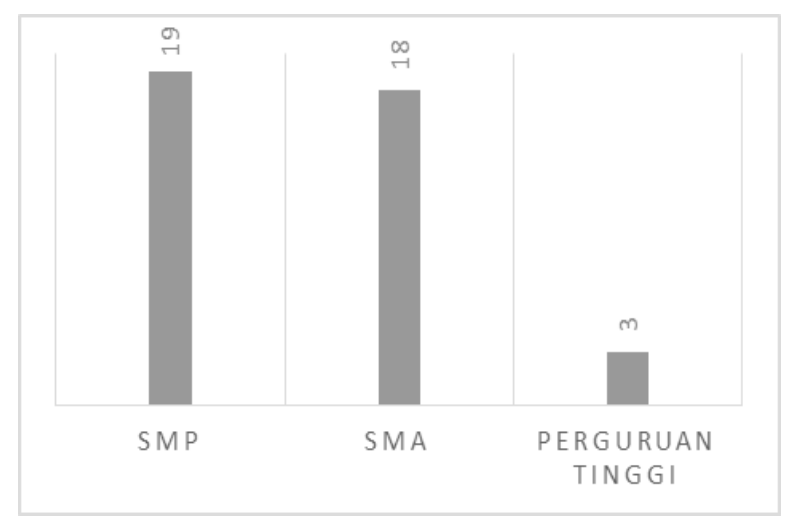

Gambar 2

Distribusi Responden Berdasarkan Tingkat Pendidikan

\section{Tingkat Stres Ibu Menyusui}

Ibu menyusui yang tidak mengalami stres (normal) sebanyak 57,5\%, sedangkan sebagian lainnya mengalami stres ringan sebanyak $25 \%$, stres sedang sebanyak 15\%, dan stres berat sebanyak $2,5 \%$. Stres pada ibu menyusui terjadi akibat ketidaknyamanan dalam menyusui, merawat diri sendiri, dan bayinya. Kondisi tersebut muncul karena ibu merasa tidak mampu menyelesaikan hal-hal yang harus dikerjakan. Kondisi akan menjadi lebih berat jika ibu tidak mampu mengatasi kesulitan yang semakin menumpuk. 


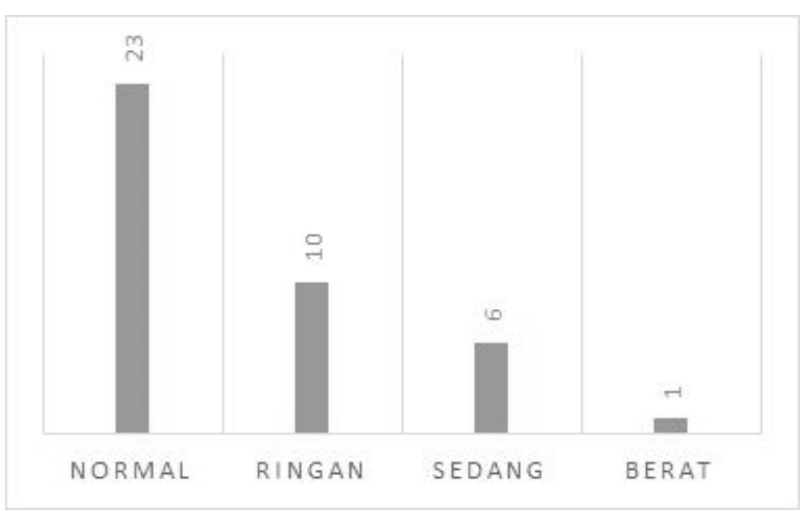

Gambar 3.

Tingkat Stres Ibu Menyusui

Stres ringan berlangsung beberapa menit atau beberapa jam. Kondisi ibu merasa gelisah karena mengalami kesulitan menyusui. Stres sedang berlangsung lebih lama, dari beberapa jam sampai beberapa hari, misalnya: ketika ibu merasa bersalah pada bayi karena ASI sedikit selama beberapa hari. Stres berat terjadi karena merasa gelisah, tertekan, sering marah, serta memiliki masalah kesehatan dalam menyusui. Kondisi tersebut berlangsung selama beberapa minggu.

Hasil penelitian menunjukkan bahwa ibu menyusui dengan stres ringan disebabkan karena merasa marah, gelisah, dan tertekan akibat terjadi sesuatu ketika menyusui atau merawat anak. Hal ini sesuai pendapat Roesli (2012) bahwa ketidaknyamanan dari sesuatu yang tidak terduga selama menyusui, misalnya, rasa mulas karena rahim berkontraksi untuk kembali pada keadaan semula, payudara bengkak, dan nyeri luka jahitan.

Tingkat stres sedang yang dialami responden terbanyak adalah merasa tidak mampu menyusui atau merawat anak serta merasakan kesulitan menyusui sehingga merasa tidak mampu untuk mengatasinya. Kondisi ini terbanyak disebabkan karena produksi ASI yang sedikit bahkan tidak keluar sehingga menimbulkan rasa bersalah karena belum bisa menyusui bayinya. Rasa bersalah tersebut dialami responden sebanyak 3-4 kali dalam sebulan.

Stres berat terjadi pada responden karena sering merasa gelisah dan tertekan dalam menyusui atau merawat anak, tidak mampu mengontrol rasa, mudah tersinggung, dan sering marah-marah. Responden pada kasus ini mengalami masalah kesehatan berupa pembengkakan payudara. Hasil kajian mendalam menunjukkan bahwa dukungan suami kurang serta ketidakmampuan ibu karena anaknya sering menangis di malam hari.

Kategori stres ibu apabila dilihat dari penyebabnya merupakan hal yang kompleks. Masa nifas merupakan periode fisiologis dimana terjadi perubahan fisiologis setelah persalinan sehingga dapat disebut stres fisiologis, namun perubahan juga terjadi pada hormon sehingga dapat pula dikelompokkan pada stres kimiawi. Masa setelah bersalin juga terjadi adaptasi psikologis akibat perubahan peran menjadi ibu sebagai bagian dari proses perkembangan, yang memungkinkan juga terjadi gangguan pada hubungan interpersonal, sosial, budaya, dan keagamaan. Masa nifas diwarnai dengan mitos, tradisi, dan kepercayaan yang beragam di masing-masing daerah.

Responden yang mengalami stres pada masa menyusui memiliki karakteristik beragam. Hasil penelitian pada Gambar 4 memperlihatkan ibu yang tergolong dalam kelompok risiko (usia kurang dari 19 tahun) lebih sedikit, mengingat persentasi responden dengan usia risiko juga lebih sedikit. Stres lebih banyak dialami pada ibu bekerja, meskipun pada pelaksanaan penelitian ibu dalam masa cuti bersalin. Tingkat pendidikan SMP lebih banyak diketahui mengalami stres daripada pendidikan SMA.

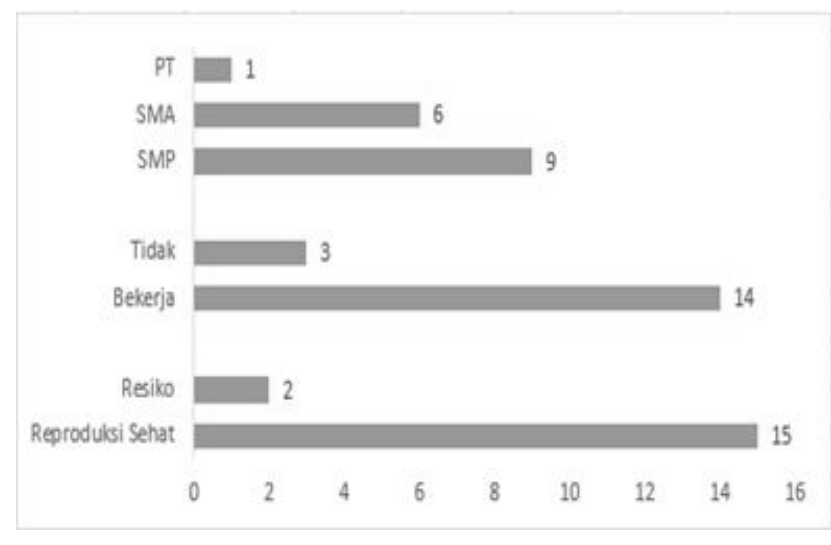

Gambar 4.

Karakteristik Responden yang Mengalami Stres 
Penelitian menunjukkan bahwa stres yang dialami terjadi karena ibu merasa tidak dapat menyelesaikan tugas-tugas yang harus dikerjakan, misalnya menyusui, merawat bayi, komunikasi dengan bayi, istirahat, dan lainnya. Ibu merasa kondisi membaik jika merasa dapat mengatasi masalahnya jika dibandingkan orang lain. Kondisi tersebut apabila tidak teratasi dapat muncul permasalahan baru dan semakin menumpuk sehingga meningkatkan tekanan (stressor) bagi ibu.

Dukungan suami dan keluarga membantu ibu mengatasi kesulitan penyesuaian dalam menjalankan peran baru. Sebagian besar responden merasa mampu mengendalikan emosi atau marah ketika mengalami masalah. Marah karena masalah yang tidak dapat dikendalikan paling sedikit dialami responden dalam masa setelah persalinan.

Permasalahan menyusui banyak terjadi pada beberapa hari setelah persalinan. Ibu merasa gelisah karena ASI tidak lancar, ASI yang keluar sedikit sehingga khawatir bayi tidak kenyang. Kegelisahan tersebut dapat teratasi jika ibu memahami fisiologi laktasi, dimana ASI secara normal keluar 2-3 hari setelah persalinan dan semakin sering menyusui semakin banyak pula ASI yang dihasilkan. Pemahaman tersebut sering kali diabaikan ketika ibu cemas dan ada dorongan dari suami atau keluarga untuk memberikan susu formula pada bayi.

Stres dapat mengganggu pencapaian tujuan menyusui ibu, misalnya penghentian menyusui lebih awal, namun tidak semua peristiwa kehidupan yang penuh tekanan dapat berdampak pada berhentinya pemberian ASI eksklusif di kalangan wanita berpenghasilan rendah. Dampak dapat berbeda menurut jenis stres. Hasil analisis yang memiliki hubungan signifikan dengan menyusui adalah tekanan finansial atau traumatis (Dozier, Nelson, \& Brownell, 2012).

Pernyataan tersebut sesuai dengan hasil penelitian dimana responden dengan status ekonomi rendah karena penghasilan keluarga diperoleh dari pekerjaan suami sebagai buruh dan petani sehingga keluarga merasa tidak mampu atau keberatan untuk membeli susu formula. Kondisi tersebut mendorong Ibu dan keluarga memutuskan untuk memberikan ASI saja. Responden yang tidak memberikan ASI disebabkan karena ASI sedikit atau bahkan tidak keluar. Sementara, untuk memperlancar produksi ASI diperlukan rangsangan berupa isapan bayi dan juga stres pada ibu dapat memengaruhi produksi ASI seperti penjelasan Susanti (2014) bahwa stres memengaruhi produksi ASI karena dapat menghambat pengeluaran ASI.

Responden yang tidak stres merasa senang menyusui bayinya dan mengatakan tidak memiliki kendala besar dalam memberikan ASI. Hasil penelitian ini sesuai dengan penelitian oleh Kamariah (2014) dimana kondisi psikologis ibu memiliki hubungan dengan kelancaran produksi ASI. Kondisi psikologis yang baik mendorong ibu untuk menyusui bayi sehingga hormon yang berperan dalam produksi ASI meningkat karena hisapan bayi ketika menyusui merangsang produksi ASI. Hasil penelitian ini juga sesuai dengan Roesli (2012) yang menjelaskan bahwa produksi ASI sangat dipengaruhi oleh faktor kejiwaan. Ibu yang mengalami gangguan emosi dapat menganggu proses let down refleks sehingga semakin sedikit pula ASI yang dikeluarkan. Sementara ASI sedikit menimbulkan perasaan untuk malas menyusui serta menimbulkan ketidaknyamanan pada ibu yang dapat memicu stres.

Penelitian dilakukan pada ibu yang tidak bekerja atau sedang menjalani masa cuti bersalin sehingga aktivitas ibu homogen yaitu terkait perawatan bayi di rumah. Kegiatan lain berupa pekerjaan dapat memberikan tekanan yang lebih besar karena ibu harus membagi waktu dan tenaga untuk buah hati, kegiatan rumah tangga, dan pekerjaan.

Tekanan lebih besar bisa dialami ibu menyusui yang juga bekerja kembali setelah habis masa cuti bersalin. Mereka yang masih dalam penyesuaian menjalankan peran ibu namun harus membagi waktu untuk bekerja. 
Analisis tentang stres pada ibu menyusui yang bekerja mengungkapkan bahwa ibu merasa "tidak menjadi ibu yang baik" dan "merasa terjebak" karena menjalankan peran tanpa dukungan yang cukup dan dampaknya terhadap kesehatan mereka (Valizadeh et al., 2016).

Ketidaknyamanan yang dialami dalam menjalankan peran sebagai ibu merupakan proses fisiologis dimana masa nifas ini adalah masa pemulihan setelah proses persalinan. Periode awal setelah bersalin ibu lebih fokus pada diri sendiri sehingga pada periode ini diperlukan pengelolaan yang tepat agar ibu tidak stres, misalnya, melalui dukungan suami dan keluarga atau tenaga kesehatan dalam kunjungan nifas karena kondisi tersebut dapat menimbulkan stres seperti yang disampaikan Amalia (2016).

\section{Pemberian ASI pada Bulan Pertama}

Hasil penelitian menunjukkan bahwa sebagian besar responden melakukan pemberian ASI pada bulan pertama sebanyak $75 \%$ yaitu sebesar 30 responden. Pemberian ASI dilakukan dengan cara menyusui bayi secara langsung. Pemberian ASI perah hanya dilakukan dalam kondisi tertentu, yaitu payudara bengkak, sakit, atau bepergian. Distribusi pemberian ASI pada bulan pertama disajikan pada Gambar 5.

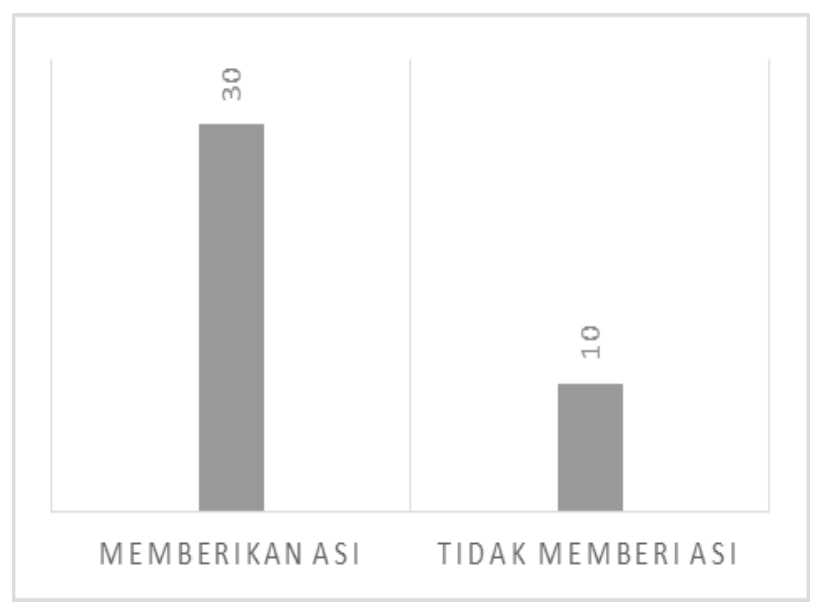

Gambar 5.

Distribusi Responden Berdasarkan Pemberian ASI pada Bulan Pertama

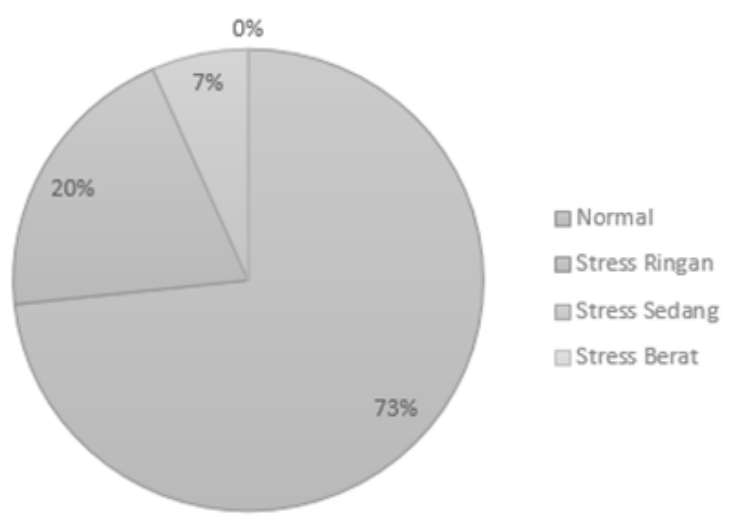

Gambar 6.

Pemberian ASI pada Bulan Pertama

Persentase responden yang memberikan ASI di bulan pertama lebih banyak karena sebagian besar responden telah mengetahui manfaat pemberian ASI di bulan pertama tersebut. Pengetahuan tentang pemberian ASI diperoleh dari kelas ibu hamil yang diselenggarakan oleh Puskesmas Tayu I. Materi terkait pemberian ASI adalah "Inisiasi Menyusui Dini (IMD)”, "ASI Eksklusif”, dan "Langkah Sukses Menyusui”.

Kajian pada kelompok responden yang memberikan ASI bisa dilihat pada Gambar 6 . Sebagian besar responden dalam kondisi normal (tidak stres), yaitu sebesar 73\%. Sebagian lain yang melakukan pemberian ASI adalah ibu yang mengalami stres ringan $(20 \%)$ dan sedang (7\%). Ibu yang mengalami stres berat tidak memberikan ASI pada bulan pertama, sehingga gelisah dan tertekan untuk menyusui.

Pemberian ASI pada bulan pertama mengalami kendala antara lain ASI belum keluar dan kekhawatiran ibu terhadap ASI yang masih sedikit sehingga dianggap tidak mencukupi kebutuhan. Kondisi tersebut memerlukan peran keluarga agar tetap mendukung ibu untuk menyusui. Menyusui memerlukan kondisi emosional yang stabil karena faktor psikologis memengaruhi produksi ASI (Oktalina, Muniroh, \& Adiningsih, 2016). Kondisi tersebut sesuai dengan hasil penelitian. Pada minggu pertama setelah bersalin dimana pengeluaran ASI belum lancar, ibu merasa cemas karena ASI yang keluar hanya sedikit dan takut bayi tidak kenyang. Dukungan suami 
dan keluarga yang membantu dalam proses menyusui bayi memberikan kenyamanan dan rasa percaya diri pada ibu untuk tetap memberikan ASI.

Hasil penelitian juga sesuai dengan penelitian oleh Wattimena dkk. (2012), dimana menyusui merupakan proses biofisiopsikologis antara ibu dan anak untuk kepentingan bersama yaitu memberikan kasih sayang dan nutrisi terbaik untuk bayinya serta manfaat kesehatan untuk ibu. Keberhasilan menyusui lebih besar jika disertai dukungan suami, keluarga, dan tenaga kesehatan

Dukungan tenaga kesehatan di wilayah kerja Puskesmas Tayu I diantaranya kelas Ibu hamil yang diikuti oleh ibu hamil selama kurang lebih 3 kali pertemuan, pendidikan kesehatan dalam kunjungan nifas, dan pertemuan lain. Penyampaian informasi dari tenaga kesehatan memberikan pengetahuan tentang ASI eksklusif termasuk kendala menyusui yang sering ditemui dan cara mengatasinya. Materi tentang ASI eksklusif diberikan pada masa kehamilan sehingga ketika bersalin ibu siap secara fisik dan psikologis untuk memberikan ASI eksklusif.

Kondisi tersebut sesuai dengan penjelasan Ernawati (2014) bahwa dukungan yang memadai dari sarana pelayanan kesehatan menunjang pemberian ASI Eksklusif. Berbeda dengan temuan peneliti sebelumnya, dimana hanya sedikit informasi tentang ASI eksklusif yang diterima dari petugas kesehatan. Puskesmas Tayu I, sebagai salah satu sarana pelayanan kesehatan di Kabupaten Pati telah menerapkan dukungan tersebut dalam bentuk pemberian informasi tentang ASI eksklusif pada program kelas ibu hamil.

Pengetahuan yang dimiliki ibu diharapkan mampu memberikan kesadaran diri untuk memberikan ASI eksklusif dan ibu mampu mengatasi ketidaknyamanan selama masa menyusui sehingga dapat menekan stres. Hal ini sesuai dengan Wattimena dkk. (2015) bahwa pemberian ASI eksklusif memerlukan manajemen diri yang kuat dalam sadar diri dan determinasi diri. Sadar diri untuk memberikan ASI sebagai nutrisi terbaik dan determinasi diri berupa motivasi untuk tetap melakukan pemberian ASI.

\section{Hubungan Tingkat Stres Ibu Menyusui dengan Pemberian ASI pada Bulan Pertama}

Hasil penelitian menunjukkan bahwa pemberian ASI dilakukan oleh ibu yang tidak mengalami stres yaitu sebanyak 55\%. Responden yang mengalami stres dan tetap melakukan pemberian ASI pada bulan pertama sebanyak $20 \%$ dengan rincian $15 \%$ pada ibu dengan stres ringan dan $5 \%$ pada ibu dengan stres sedang. Responden yang tidak memberikan ASI pada bulan pertama sebagian besar mengalami stres, meskipun ada yang dalam kondisi normal atau tidak stres yaitu sebesar $2,5 \%$.

Tabel 1 menunjukkan tabulasi silang hasil penelitian, dimana ibu yang tidak mengalami stres (normal), namun tidak memberikan ASI sebanyak 2,5\%. Responden yang termasuk dalam kategori tersebut memiliki kesamaan karakteristik pekerjaan suami sebagai buruh, sedangkan tingkat pendidikan bervariasi pada

Tabel 1.

Tingkat Stres Ibu Menyusui dengan Pemberian ASI pada Bulan Pertama

\begin{tabular}{lccc}
\hline \multirow{2}{*}{ Tingkat Stres Ibu Menyusui } & \multicolumn{2}{c}{ Pemberian ASI pada Bulan Pertama } & \multirow{2}{*}{$\begin{array}{c}\text { Total } \\
\text { (\%) }\end{array}$} \\
\cline { 2 - 3 } & diberikan (\%) & tidak (\%) & 57,5 \\
\hline Normal & 55 & 2,5 & 25 \\
Stres Ringan & 15 & 10 & 25 \\
Stres Sedang & 5 & 10 & 2,5 \\
Stres Berat & 0 & 2,5 & 100 \\
Total & 75 & 25 & 5 \\
\hline
\end{tabular}

Sumber: Data Primer (2018) 
Tabel 2.

Penggabungan Sel Tingkat Stres Ibu Menyusui dengan Pemberian ASI pada Bulan Pertama

\begin{tabular}{lcc}
\hline \multirow{2}{*}{ Tingkat Stres Ibu Menyusui } & \multicolumn{2}{c}{ Pemberian ASI pada Bulan Pertama } \\
\cline { 2 - 3 } & diberikan (\%) & tidak (\%) \\
\hline Normal-Ringan & 82,4 & 17,6 \\
Sedang-Berat & 33,3 & 66,7 \\
Total & 75 & 25 \\
\hline
\end{tabular}

Sumber: Data Primer (2018)

tingkat SMP dan SMA. Ibu yang mengalami stres berat tidak ada yang memberikan ASI, namun ada juga ibu dengan tingkat stres sedang dan tetap memberikan ASI yaitu sebanyak $5 \%$.

Hasil penelitian tidak memenuhi syarat pengujian chi square sehingga dilakukan penggabungan sel (tercantum pada Tabel 2) dan diperoleh nilai $p$ value 0,041 yang berarti bahwa ada hubungan tingkat stres ibu menyusui dengan pemberian ASI pada bulan pertama. Hasil uji statistik menggunakan odds ratio (OR) sebesar 9,33 (95\% CI =1,38 sampai 63,20 ) yang berarti respoden dengan tingkat stres sedang-berat mempunyai kemungkinan 9,33 lebih besar untuk tidak memberikan ASI pada bulan pertama

Masa bulan pertama setelah melahirkan, dalam hal ini semua responden adalah primigravida, sedang menjalankan peran baru. Ibu dalam masa pemulihan kondisi setelah bersalin disamping tugas merawat bayi,

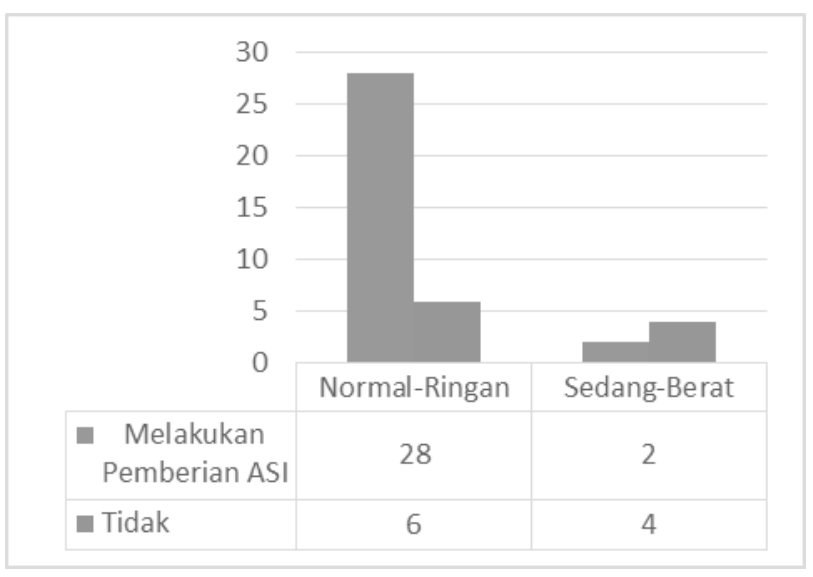

Gambar 7.

Tingkat Stres dan Pemberian ASI pada Bulan Pertama (Penggabungan Sel) terlebih beberapa ibu juga tetap melakukan aktivitas rumah tangga. Ibu bisa mengalami kelelahan, terjadi ketegangan emosional sehingga ASI tidak lancar yang pada akhirnya pemberian ASI berhenti lebih awal. Hal tersebut sesuai yang dijelaskan Hardiani (2017) bahwa ketegangan emosi dapat menurunkan produksi ASI.

Berdasarkan stres model stimulus oleh Gaol (2016) bahwa ketika seseorang gagal menyesuaikan dengan situasi atau perubahan dapat menimbulkan dampak buruk, misalnya, perasaan cemas. Kondisi tersebut sering dialami dalam penyesuaian peran menjadi ibu setelah melahirkan. Ibu merasa cemas ketika ASI tidak keluar, ibu merasa tidak mampu menyusui bayinya. Ibu menyusui mengalami disstres yaitu stres yang mengakibatkan dampak buruk berupa penurunan produksi ASI, maupun gangguan hubungan dengan orang lain (tidak mau menyusui bayinya).

Stres pada ibu memiliki korelasi negatif terhadap kandungan lemak pada ASI yang dihasilkan (Gottfredson, 2015). Kandungan lemak yang kurang membuat bayi kurang kenyang sehingga bayi menjadi gelisah. Ibu yang mengalami stres perlu mendapatkan pengelolaan stres sehingga pemberian ASI dapat dilakukan dengan efektif. Tenaga kesehatan dapat memberikan informasi mengenai mekanisme koping untuk mengurangi tingkat stres pada ibu menyusui.

Hasil penelitian sesuai dengan penelitian Hobbs et al. (2016) bahwa pemberian ASI dipengaruhi kesehatan fisik dan mental. Temuan menunjukkan persalinan SC yang direncanakan memiliki peluang pemberian ASI lebih singkat. 
singkat. Persalinan SC yang disebabkan oleh kondisi darurat dapat memicu respons stres ibu yang lebih besar.

Hal serupa dengan penelitian Cato et al. (2017) dimana stres yang dialami pada masa kehamilan berkaitan dengan lama menyusui. Hubungan antara stres emosional selama kehamilan dengan pemberian ASI pada dua bulan pertama disebabkan oleh kepercayaan diri yang rendah, depresi dan/atau kecemasan sebelum atau selama kehamilan dan postpartum, serta faktor-faktor yang diketahui secara negatif memengaruhi durasi menyusui.

Kajian tentang dampak stres terhadap pemberian ASI juga dilakukan Evans (2017) bahwa produksi ASI terkait dengan stres dan dukungan sosial yang dirasakan. Ibu dengan berbagai ras diketahui stres berkaitan dengan beban tangung jawab dalam merawat bayi dan kurangnya dukungan dalam pemberian ASI. Pekerjaan dan aktivitas rumah tangga yang banyak mengakibatkan kelelahan yang memicu penurunan produksi ASI. Ibu yang mengalami stres akan terjadi blokade dari reflek letdown. Selain itu, ibu yang merasa tertekan, sedih, kurang percaya diri, dan berbagai ketegangan emosional termasuk ketegangan internal dalam keluarga maupun pekerjaan dapat menurunkan produksi ASI (Hardiani, 2017).

Hasil analisis karakteristik responden berdasarkan umur dan tingkat pendidikan diketahui bahwa masing-masing karakteristik tersebut tidak terdapat hubungan dengan pemberian ASI pada bulan pertama. Hal ini dimungkinkan karena informasi tentang pemberian ASI dapat diperoleh dari berbagai sumber baik dari media, media sosial, tenaga kesehatan, teman, dan lainnya tanpa mempertimbangkan umur dan pendidikan seseorang. Hal ini berbeda dengan penelitian Rosita \& Imrohwati (2016) yang menuliskan bahwa pendidikan dapat memengaruhi pemberian MP-ASI dini pada bayi usia 0-6 bulan. Seseorang dengan tingkat pendidikan yang lebih tinggi diharapkan lebih baik menerima informasi tentang pemberian ASI saja sampai bayi usia 6 bulan dan dapat menerapkan informasi yang telah diperoleh dalam kehidupan sehari-hari.

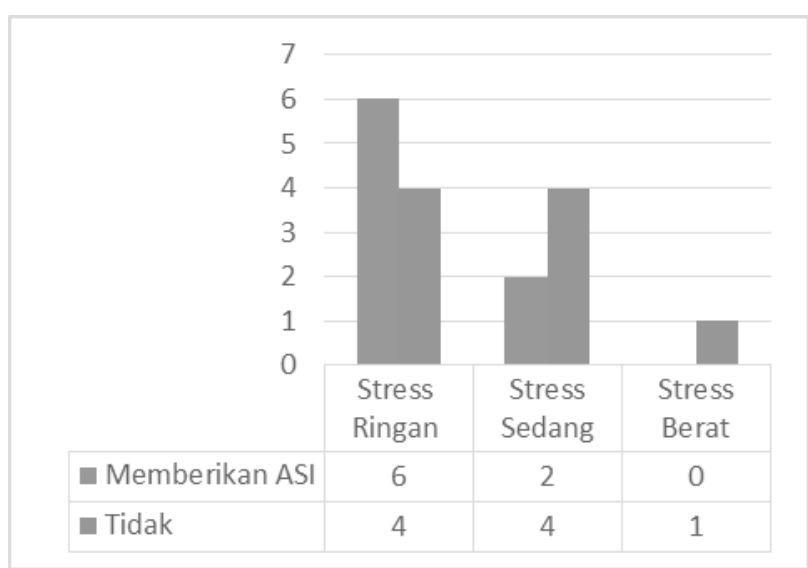

\section{Gambar 8.}

Pemberian ASI pada Bulan Pertama pada Kelompok Ibu Menyusui Menurut Tingkat Stres

Temuan serupa terkait umur ibu sesuai penelitian Evans (2017) dimana keberhasilan menyusui berhubungan dengan umur ibu. Faktor lain yang berkaitan dengan keberhasilan menyusui adalah keinginan atau motivasi menyusui dan akses yang mendukung pemberian ASI sampai bayi umur 6 bulan.

Hasil penelitian memperlihatkan bahwa ibu yang mengalami stres memiliki kecenderungan penurunan memberikan ASI pada bayinya. Kelompok ibu menyusui normal (tidak stres) memberikan ASI pada bulan pertama sebesar $96 \%$ yaitu 22 dari 23 ibu memberikan ASI.

Analisis pada kelompok ibu yang mengalami stres dapat dilihat pada Gambar 8. Kelompok ibu yang mengalami stres terdapat penurunan persentase memberikan ASI dibandingkan dengan peningkatan tingkat stresnya. Ibu yang mengalami stres ringan dan memberikan ASI sebesar 35\%, ibu dengan stres sedang dan memberikan ASI sebesar $12 \%$.

Penelitian memperlihatkan ibu dengan tingkat stres sedang, namun tetap memberikan ASI, sejalan dengan pendapat Elsanti \& Isnaini (2018) dimana terdapat ibu yang mengalami stres, namun berhasil memberikan ASI karena adanya motivasi dan dukungan sosial yang tinggi agar selalu berupaya meningkatkan produksi ASI dan selalu memberikan ASI. Motivasi dan dukungan diperoleh dari keluarga, lingkungan, dan tenaga kesehatan. 
Keyakinan yang tinggi untuk menyusui (breastfeeding self efficacy) membuat ibu lebih gigih untuk tetap menyusui. Keyakinan tersebut dapat muncul dari pengalaman (Pradanie, 2015). Pengalaman langsung dalam penelitian ini merupakan pengalaman pertama ketika menyusui, segera setelah bersalin. Pengalaman tidak langsung diperoleh dari informasi terkait dalam kelas ibu hamil dan pendidikan kesehatan lainnya.

Ibu menyusui dengan stres berat tidak melakukan pemberian ASI karena kondisi yang dialami, namun disisi lain terdapat ibu yang tidak mengalami stres namun juga tidak memberikan ASI pada bulan pertama. Ibu yang tidak memberikan ASI diantaranya karena tidak merasa percaya diri apakah bisa menyusui bayi. Faktor lain yaitu kurangnya dukungan keluarga, seperti penelitian Khayati \& Ulfa (2018) dimana dukungan keluarga berupa dukungan emosional dan informasional. Dukungan tersebut memberikan motivasi agar tetap menyusui.

Hasil penelitian juga selaras dengan penelitian Nurhamidah \& Kuntoro (2016) yang menemukan kegagalan pemberian ASI eksklusif akibat kurang dukungan dari tenaga kesehatan. Penelitian menemukan bahwa sebagian responden menerima saran dari tenaga kesehatan untuk memberikan susu formula karena ASI kurang. Hal tersebut menjadikan tempat bersalin sebagai kunci pertama pelaksanaan inisiasi menyusui dini sehingga pemberian ASI dapat diberikan setelahnya dan menganjurkan pemberian ASI saja sampai bayi usia 6 bulan.

Manajemen stres merupakan salah satu alternatif metode untuk menciptakan koping positif agar ibu memiliki pandangan dan kepercayaan untuk berhasil menyusui. Paket dukungan termasuk di dalamnya manajemen stres postpartum. Pradanie (2015) menyatakan breastfeeding self efficacy berhubungan dengan tindakan pemberian ASI secara eksklusif. Breastfeeding self efficacy yang kuat membuat ibu tetap menyusui meskipun mengalami kendala pada bulan pertama menyusui.

\section{KESIMPULAN DAN SARAN}

\section{Kesimpulan}

Stres sering terjadi pada bulan pertama karena adaptasi menjalankan peran baru sebagai ibu sehingga dapat menghambat pengeluaran ASI. Kondisi ini jika dibiarkan dapat mengganggu pemberian ASI eksklusif selama 6 bulan dan berdampak terhadap ibu dan bayi. Berdasarkan hasil penelitian dapat disimpulkan bahwa Ibu menyusui sebagian besar tidak mengalami stres, dan diantara ibu yang mengalami stres sebagian besar pada tingkat ringan. Pemberian ASI pada bulan pertama sebagian besar dilakukan oleh ibu yang tidak mengalami stres. Terdapat hubungan antara tingkat stres ibu menyusui dengan pemberian ASI pada bulan pertama. Ibu yang tidak mengalami stres dan stres ringan mempunyai kemungkinan lebih besar untuk tetap melakukan pemberian ASI pada bulan pertama.

\section{Saran}

Pada periode pascapersalinan ibu perlu mendapatkan dukungan dan bantuan dari suami, keluarga dan tenaga kesehatan sehingga terhindar dari tekanan atau kondisi lain yang memicu stres. Program pendampingan terutama pada minggu pertama karena secara fisiologis, produksi ASI dimulai 2-3 hari setelah melahirkan dan di sisi lain, ibu perlu adaptasi melaksanakan peran barunya.

Dukungan nyata dari lingkungan, baik suami, keluarga, maupun tenaga kesehatan membuat ibu merasa nyaman dan terhindar dari stres sehingga produksi ASI juga meningkat. Kesuksesan pemberian ASI pada awal periode sebagai kunci keberhasilan pemberian ASI eksklusif. Bentuk dukungaan atau program pendampingan dipertimbangkan secara efektif dan efesien, misalnya, dengan peningkatan jaringan sosial. Informasi dapat diakses secara mudah dan cepat serta memungkinkan konsultasi masalah pemberian ASI tanpa tatap muka secara langsung. 


\section{DAFTAR PUSTAKA}

Amalia, R. (2016). Hubungan Stres dengan Kelancaran ASI pada Ibu Menyusui Pascapersalinan di RSI A. Yani Surabaya. Jurnal Ilmiah Kesehatan, 9(1), 12-16.

Arikunto, S. (2013). Prosedur Penelitian Suatu Pendekatan Praktik. Jakarta: Rineka Cipta.

Cato, K., Sylvén, M. S., Lindbäck, J., Skalkidou, A., \& Rubertsson, C. (2017). Risk Factors for Exclusive Breastfeeding Lasting Less than Two Months - Identifying Women in Need of Targeted Breastfeeding Support. PLoS ONE, 12(6), 1-13.

Dinas Kesehatan Kabupaten Pati. (2018). Profil Kesehatan Kabupaten Pati Tahun 2017. Pati: DKK Pati

Dozier, A. M., Nelson, A., \& Brownell, E. (2012). The Relationship between Life Stres and Breastfeeding Outcomes among LowIncome Mothers. Advances in Preventive Medicine, 2012, 1-10.

Elsanti, D., \& Isnaini, O. P. (2018). Hubungan antara Dukungan Sosial dan Tingkat Stres terhadap Keberlangsungan Pemberian ASI Eksklusif di Wilayah Kerja Puskesmas Kedungbanteng.Jurnal Ilmu Keperawatan Maternitas, 1(1), 13-25.

Ernawati, A. (2014). Peranan Sarana Pelayanan Kesehatan dalam Pemberian ASI Eksklusif: Studi pada Pegawai Negeri Sipil di Kecamatan Pati. Jurnal Litbang Pati: Media Informasi, Penelitian Pengembangan IPTEK, $\mathrm{X}$ (2), 133-42.

Evans, B. (2017). Psychosocial Stres, Race, and Social Support among Breastfeeding Mothers in the American South (Thesis). https://schoolarworks.gsu.edu/ anthro_theses/123.

Gaol, NTL. (2016). Teori Stres: Stimulus, Respons, dan Transaksional. Buletin Psikologi, 24(1), 1-11.
Gottfredson, L. M. (2015). Maternal Stres, Breastmilk IGF-1, and Offspring Growth among Breastfeeding Mothers-Infant Pairs in the Tampa Bay Area. (Graduate Theses and Dissertations). http:// scholarcommons.usf.edu/etd/5690

Hardiani, R. S. (2017). Status Paritas dan Pekerjaan Ibu terhadap Pengeluaran ASI pada Ibu Menyusui 0-6 Bulan. NurseLine Journal, 2(1), 44-51.

Hobbs, A. J. Mannion, C. A., McDonald, S. W., Brockway, M., \& Tough, S. C. (2016). The Impact of Caesarean Section on Breastfeeding Initiation, Duration and Difficulties in the First Four Months Postpartum. BMC Pregnancy and Childbirth, 16(1), 1-9.

Isaacs. (2012). Panduan Belajar: Keperawatan Kesehatan Jiwa dan Psikiatri. Jakarta: EGC.

Kamariyah, N. (2014). Kondisi Psikologi yang Memengaruhi Produksi ASI Ibu Menyusui di BPS Aski Pakis Sido Kumpul Surabaya. Jurnal Ilmiah Kesehatan, 7(12), 29-36.

Kementerian Kesehatan RI. (2014). Pedoman Penyelenggaraan Pelatihan Konseling Menyusui dan Pelatihan Fasilitator Konseling Menyusui. Jakarta: Direktorat Jenderal Bina Kesehatan Masyarakat Kemenkes RI.

Kementerian Kesehatan RI. (2018). Profil Kesehatan Indonesia 2017. Jakarta: Kemenkes RI

Khan, J., Vesel, L, Bahl, R., and Martines, J. C. (2015). Timing of Breastfeeding Initiation and Exclusivity of Breastfeeding During the First Month of Life: Effects on Neonatal Mortality and Morbidity-A Systematic Review and Meta-Analysis. Maternal and Child Health Journal, 19(3), 468-79.

Khayati, F. Nur., \& Ulfa, Z. D. (2018). Dukungan Pemberian ASI Eksklusif pada Ibu Bekerja. Jurnal Smart Kebidanan, 5(2), 11-17.

Nurhamidah \& Kuntoro. (2016). Peran Karakteristik Responden dan Dukungan Tenaga Kesehatan dalam Identifikasi Faktor yang Terkait dengan Kegagalan Pemberian ASI Eksklusif. Jurnal Biometrika dan Kependudukan, 5(1), 52-60. 
Oktalina, O., Muniroh, L., \& Adiningsih, S. (2016). Hubungan Dukungan Suami dan Dukungan Keluarga dengan Pemberian ASI Eksklusif pada Ibu Anggota Kelompok Pendukung ASI (KP-ASI). Media Gizi Indonesia, 10(1), 64-70.

Potter, P. A., \& Griffin, P. A. (2012). Fundamental Keperawatan: Konsep, Proses, dan Praktis, Edisi Pertama. Jakarta: EGC.

Pradanie, R. (2015). Paket Dukungan terhadap Breastfeeding Self Efficacy dan Keberhasilan Menyusui pada Ibu Postpartum. Jurnal Ners, 10(1), 20-29.

Roesli, U. (2012). Mengenal ASI Eksklusif. Jakarta: Trubus Agriwidya.

Rosita, E., \& Imrohwati, D. (2016). Hubungan Tingkat Pendidikan Ibu dengan Pemberian MP-ASI Dini pada Bayi Usia 0-6 Bulan. Midwifery Journal of Stikes Insan Cendekia Medika Jombang, 11(1), 11-15.

Susanti. (2014). ASI Eksklusif. Jakarta: Pustaka Swara.

UNICEF, \& WHO. (2015). Advocay Strategy: Breastfeeding Advocacy Initiative, for the Best Start in Life.

Valizadeh, S., et al. (2016). Perceived Stress in Breastfeeding Working Mothers in Iran. International Journal of Medical Research \& Health Sciences, 5(11), 485-92.
Wattimena, I., Susanti, N. L., \& Marsuyanto, Y. (2012). Kekuatan Psikologis Ibu Untuk Menyusui Women. Kesmas, National Public Health Journal, 7(2), 56-62.

Wattimena, I., Werdani, Y. D. W., , Bernadette D. Novita, B. D., \& Liona, D. A. (2015). Manajemen Laktasi dan Kesejahteraan Ibu Menyusui. Jurnal Psikologi, 42(3), 231-42.

WHO. (2016). Infant and Young Child Feeding. Geneva: WHO Press.

\section{BIODATA PENULIS}

Zuly Daima Ulfa, lahir pada tanggal 10 Juli 1985 di Pati. Magister Kesehatan Masyarakat dari Universitas Negeri Semarang. Saat ini bekerja sebagai Bidan di Klinik dan sebagai dosen di Universitas Palangka Raya, pada Program Studi Pendidikan Jasmani, Kesehatan dan Rekreasi.

Yuli Setyaningsih, lahir tanggal 29 Oktober 1973 di Pati. Pendidikan terakhir adalah Sarjana Terapan Kebidanan Stikes Karya Husada Semarang. Saat ini bekerja sebagai bidan di Puskesmas Tayu I Kabupaten Pati. 